\title{
Security for Enhancing Peace and Stability in Changing Context of Nepal ${ }^{1}$
}

\author{
Bishnu Raj Upreti, PhD \\ Adjunct Professor and Supervisor for Masters and $\mathrm{PhD}$, \\ Kathmandu University and Agriculture \& Forestry University, Nepal \\ Research Director, Nepal Centre for Contemporary Research \\ Member of Board of Trustees, International Foundation for Science \\ Member of Advisory Board, Centre for Unconventional Security Affairs, \\ University of California, Irvine \\ Email: bishnu@nccr.org.np
}

\begin{abstract}
The world is facing new security challenges in 21 st century that has forced global and national security actors to think differently. Unconventional security issues such as resource scarcity, climate change effects, livelihood insecurity, environmental insecurity, food and water insecurity, health insecurity, natural calamities and disasters, pandemic diseases, etc. are now integral part of security going beyond conventional security issue of protecting sovereignty and territory of the state. Further, Nepal has also specific geopolitical and geo-strategic issues and challenges emerged from the Sino-Indian dynamics. Global economic and strategic power is shifting from US to China and therefore China will be most influential in the world order in coming few decades. Similarly, India is also rapidly expanding its influence in global and regional sphere. Hence, small countries like Nepal will have both negative and potentially positive efforts (economically, politically, strategically) to deal in the changing global order (protecting national interests in a situation of aggressive approaches of old and emerging powers) in the context of China-India revelry. As Nepal is having rapid change in political and strategic sphere advancement of security sector is eminent. However, dealing with new security challenges requires enabling environment (favourable legal-regulatory provisions, supportive institutional arrangement, required resources, investing in capacity development especially in education and research, developing sound intelligence and integrating security policy with international relations, economic development and social services). Hence, it is essential to expand security discourse and engage citizen to develop ownership, strengthen the National Security Council, create enabling environment (developing relevant policy and strategies, promulgation of laws and development of rules and procedures, creating responsive institutional mechanisms, developing capabilities, making required resources available, parliamentary oversight and monitoring provisions, invest in security research and education) to address emerging new security challenges of the 21 st century.
\end{abstract}

Key Words: Challenges, Nepal, peace, stability, security

\section{Introduction}

Security is a major concern at present context. It is conceptually interdependent, methodologically complex and strategically fundamental to secure nation's social, economic and political interests against the threats arising from other states (Huntington, 1985) and to protect its citizens (Upreti et al., 2013; Upreti, 2009a). Though security in the conventional notion is interpreted in the frame of national security to be provided by security forces with major role of military using different strategies and activities that minimise or neutralise the efforts of external actors (mainly from other independent nations), the modern concept of security goes beyond conventional scope and deals with societal and human security issues (Upreti et al, 2015; Upreti 2014; Upreti \& Vanhautte, 2009; Hough, 2004). Security debate in changing context needs to look from this background. Hence, while envisioning the Nepal's security the components of the following figure provides the board purpose.

Figure 1 below provides an overview of the Nepal's long term security vision where three complementary building blocks are identified. They are: a) security (3 components of security are state security, human security and societal security), b) basic elements of the peace (4 components are namely equity, justice, human rights and dignity), and c) stability (3 important components are namely political

\footnotetext{
${ }^{\mathbf{1}}$ This paper is revised and updated version of the chapter 6 (I wrote) entitled 'security for peace and stability by 2030' of the book entitled Nepal Vision 2030 edited by SR Sharma, B. R. Upreti and K. N. Pyakuryal (2012) and published by Kathmandu University and NCCR.
} 


\section{2 | Journal of APF Command and Staff College}

stability, economic stability and social stability). The term comprehensive security or holistic security frequently used in this paper refers to these 3 interdependent components presented in the figure 1 .

Figure 1: Nepal's Long Term Security Vision

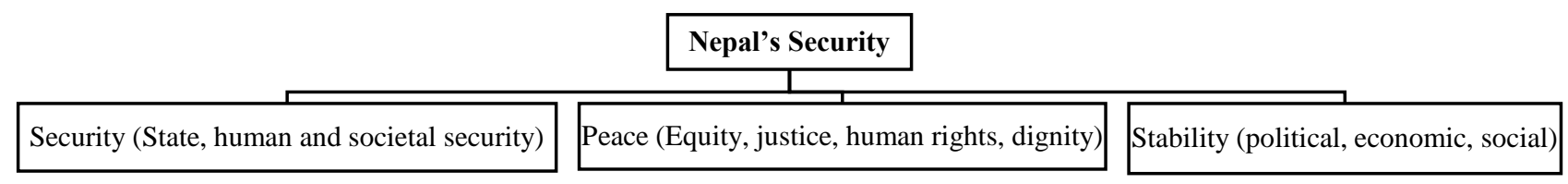

Source: Adapted from Upreti, 2012b

Historically, Nepal's security concerns were dominated by the state security and security of heads of the fiefdoms, kingdoms and elites surrounding the power. During the time of Rana Rule and Panchayat regime security arrangements: policy and strategies, laws, rules and procedures, institutional mechanisms, capabilities, resources, and monitoring provisions were narrowly focused. Laws and regulations were developed and used accordingly (Phuyal \& Urscheler, 2010). Ad hoc security policy guidelines were issued considering the context. No comprehensive national security policy was developed and applied. Even until few years back there was no separate national security. Security debate was limited to military and police (Bhattarai \& Cave, 2009) because of lack holistic understanding of political and policy decision makers. Since last one decade the security debate is moving fast that resulted in a National Security Policy, which goes beyond the understanding of security is the only responsibility of security forces. The strong perception of security is only related military and debate initiated outside the security actors is seen as intrusion in their territory. In the past one debate military, police and scholars are critically reflecting on need of comprehensive security, engaged in informed debate and early warning based on the analysis of strengths, weaknesses, opportunities and challenges of security forces, which is needed to further advance. Understanding are gradually developed and space for security debate is quite expanded (Upreti et al. 2013; Upreti 2014, Upreti 2016).

Even when the multiparty democratic political system was started in 1990, the security debate was not much on public reach mainly because:

- Security was narrowly understood. It was under the shadow of the Palace and therefore it was out of debate and reform agenda. Politicians were not able visualise security as public concern and to be debated in public. Hence, it was not their agenda debate and modernization. They were entirely relying with security forces on strategic issues instead of engaging and updating with the recent development in security thinking. Consequently, they prefer to avoid engaging themselves in the national debate on need for a new vision of security to address emerging security challenges such as climate security, human security, and societal security. The space for debate was formally opened by the Comprehensive Peace Agreement (CPA) especially with the provision to integrate and rehabilitate Maoist combatant army. This provision forced to initiate and to engage in security debate and researchers, practitioners, policy makers started examine different dimensions of security. But still performance of political leaders in this issue weak for appropriately handling crucial contemporary security issues (Upreti 2012, Upreti et al 2016).

- Security forces for long were trained and nurtured in such a way that security issues belong only to them and therefore they perceived that the debate going beyond their circle is encroachment in their territory. Such feelings and perceptions have overtly or covertly developed resistance on security forces to collaborate with wider groups working on security issues. Consequently no informed constructive debate on new security challenges and ways of addressing them for long.

- As new security challenges were not debated widely, decision makers working on the security issues were less informed, less engaged. Therefore new security challenges were not comprehensively reflected in the national polices, strategies, regulatory frameworks and institutional arrangements.

- There were no systematic efforts on ensuring institutional arrangements for academic programme (education), research and public debate on security issues for long and since few years security institutions in collaboration with the Tribhuvan University started it but still week. There are not yet well established think tanks, higher academic courses and specialized research centres related to security issues that undermine the meaningful and constructive engagement of general public in national security debate. 
- National Interests Protection Committee of the Constituent Assembly had opened the debate and at envisioned holistic security for this country. However, without sound research, grounded analysis, constructive debate, the efforts were insufficient. Nevertheless, positive provisions were incorporated in the new constitution.

While looking to the existing situation, following are some of the most common features (from the governance and institutional perspectives) observed in security sector of Nepal:

- Conceptual understanding: Security policy makers and decision makers (at both political and security levels) are yet to fully internalize the holistic security perspective going beyond sector or individual organizational scope because of the reasons discussed in the section one. Nepal's security policy makers still need to expand their understanding of new concepts; unconventional security challenges and political economy of global security. It is essential to move from conventional understanding of security as a domain of military or government's security bodies and look for holistic security framework to deal with the security challenges of $21^{\text {st }}$ century. It is essential now to operate higher education in security issues, established thematic security think-tanks and invest in research and capacity building to address the new security challenges.

- Allocation, use and distribution of budget: Insufficient allocation or misplaced priority or contested and sometime even questioned by Parliamentary Committees. Hence, addressing these issues is essential to improve performance of security sector.

- Promotion, reward and punishment: More work is needed on these issues to enhance reputation and performance of security sector. Transparent, fair and timely promotion, rewards, trainings and capacity building are core for modernization and strengthening the security organizations.

- Internalisation of rule of law: One of the important elements of successful modern security organizations is to internalize rule of law and operate in this spirit. Selective use of law and use as per the convenience is detrimental for any security organizations. Hence, security organizations and oversight mechanisms need to work together to transparently implement the rule of law.

- Service to ordinary people: Owing heart and mind of ordinary people is the most important aspect of enhancing the civilian-security relation and for that easy access of ordinary people to security services is the prime condition. It enhance public ownership of security organizations, minimise misunderstanding and gap between civilian and security forces, and develop confidence, trust and mutual respect which is the core of success of security organizations.

- Efficiency and effectiveness of resources: Efficiency and effectiveness are two crucial elements of modernization of the security organizations. Resources are often scarce and need judicial allocation and transparent use. Security organizations have to work on traditional as well as modern/unconventional security challenges and therefore required to be equipped with scientific technology and equipment. So, judicial allocation of resources and transparent are key for security organizations to success.

- Political interference: Security sector, especially police force is permanently suffered from the rampant political interference and ultimately discrediting and dysfunctionalize security organization. Therefore it is a collective responsibility of the parliament (to bring law to keep security forces away from political interference and parliamentary oversight), the government (ensure that security organizations are operating independently as per their mandate and legal framework without external interference).

- Civilian-security relations: A good relation of security forces with civilian is a key to success. Often, in difficult time (armed conflict and war, political unrest, etc.) security forces focuses on the main objectives and undermine civilians or ignore the importance of establishing good relations with ordinary people and later face different consequences of abusive acts. Hence, one of the important work of security organizations to enhance relations with general public. In the past few years security forces of Nepal are well aware of importance of this aspect and working on it but it needs to make more regular, important task.

The points discussed above clearly demonstrate the need as well as progress made in dealing with the new security challenges in relations to our security arrangements (policy and strategies, laws, rules and procedures, institutional mechanisms, capabilities, resource-base and monitoring provisions). Nepal's 


\section{4 | Journal of APF Command and Staff College}

security sector learned from trial and error, learning by doing and institutional legacies but moving to right direction to tackle security challenges of the $21^{\text {st }}$ century. The scope of this paper is not a SWOT (strengths, weakness, opportunities and threats) analysis of the security organizations operating in Nepal but to very quickly reflect the situation and envision new security discourses that contains emerging security dimensions in addition to conventional one. Therefore, all dimensions of existing security organizations are not part of the paper. The main focus of the paper is to bring holistic focus (state security, human security and societal security) in public debate and help to concerned stakeholders and policy makers to promote comprehensive security in the country.

\section{Changing Context and Need for a Wider Security Discourse}

Nepal has frequently rewritten political history. The political changes of 1951, 1990 and 2006 laid foundation for a transformation of a centralised, monarchical, exclusionary state into a modern inclusive nation. However, political parties and their leaders are repeatedly failed to manage the change as per the expectation of Nepali people (Sharma et al 2012; Upreti et al 2016). In the past 12 years, entire political processes were focused on managing transition and ensuring fundamental restructuring of the nation (Upreti, 2010). The CPA had provided broader framework and 'transformational skeleton' on which the Constituent Assembly together with political parties worked further and institutionalised changes brought by the political movements. However, delivery of the constitutional provisions to server ordinary citizen of Nepal is weak and frustrating. Security is one of several sectors of the state such as judiciary, bureaucracy, legislatives to deliver service to people (Upreti, 2009b) and security sector alone cannot deliver security if other sectors are not operating properly. Hence, their role is complementary to provide services of people and improving the existing economic, social, political, cultural-religious practices (Upreti, 2010).

For long, Nepal's security sector faced institutional and governance bottleneck. Institution in this paper covers the organisational dimensions as well as the rules, procedures and value systems of security organizations such as Nepal Army, Armed Police Force, Nepal and Nepal Police. Governance of the state security organisations for this paper is a process of translating policies and regulations into practices including balance of confidentiality and transparency, accountability, application of rule of law, efficient and effective use of available resources, respecting basic human rights principles and humanitarian law as well as parliamentary oversight and civilian control. Nepali security forces sent abroad for UN peace keeping operation and other purposes have demonstrated excellent performance and built high reputation but Nepali political decision makers are not able maximize potential opportunities arise from such good performance. Why? Answer to this issue is lack of diplomatic efforts, lack of internalization of the achievements made in this area or ignorance that need to change. Role played by security forces especially in UN peace keeping operation is special strength of Nepal's security forces and therefore it essential to expand and use for diplomatic purpose (enhancing visibility and importance of Nepal in the world affairs). Examining the effectiveness of security agencies, effective institutional arrangements (in terms of service delivery, resource use, neutrality and free from politicization), motivated, well trained and committed human resources, adequate legal framework and appropriate security policy (that encompasses strategy, procedures, oversight mechanisms, civilian control) presented in the Figure 2 utmost essential.

Figure 2: Components for Effective Security Service Delivery by the Security Agencies

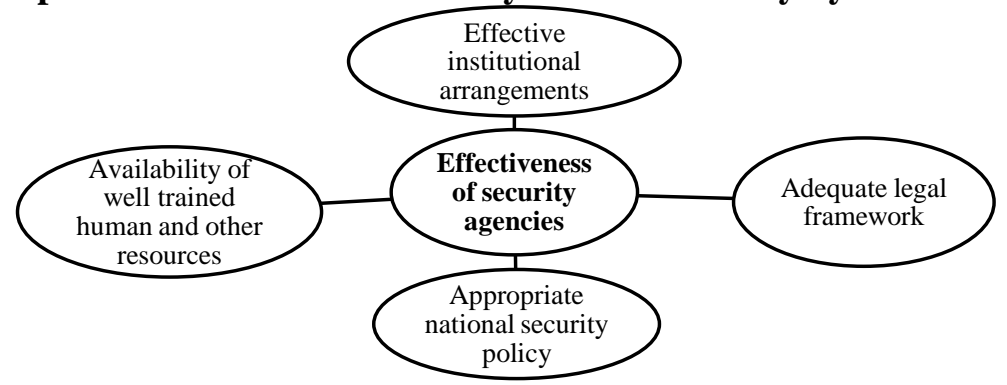

Source: Upreti (2012b)

\section{Quick Envisioning of Future Security}

The future security discourse are shaped by 4 important global dynamics i.e., global security, global economic and regional dynamics, global political dynamics and global technological advancement. 
Future security of any country is shaped by these dynamics and therefore preparing the Nepal's security visions for coming several decades depends upon these four factors (see Figure 3 about each of them).

Figure 3: Four Interrelated Dimensions That Affect Future Security Debate

\begin{tabular}{|c|c|}
\hline $\begin{array}{c}\text { The global and regional economic dimensions } \\
\text { Emergence of new economic powers } \\
\text { Economic crisis and rescissions } \\
\text { Globalization and knowledge based economy } \\
\text { Resource scarcity and competition } \\
\text { Weakening of poor/small countries by economic crisis } \\
\text { Growing consumerism; Aid conditionality }\end{array}$ & $\begin{array}{c}\text { The global security dimensions } \\
\text { Use of military forces/weapons of mass destruction, } \\
\text { Wars and conflicts; Environmental insecurity } \\
\text { Health, water and food insecurities } \\
\text { Proliferation Small arms and light weapons } \\
\text { Terrorism and counter-terrorism } \\
\text { Pandemics and natural calamites }\end{array}$ \\
\hline \multicolumn{2}{|c|}{$\left[\begin{array}{c}\text { Global context and emerging security issues } \\
\text { for National Security vision for Nepal }\end{array}\right]$} \\
\hline $\begin{array}{l}\text { Technological advancement } \\
\text { Manufacture of nuclear, chemical, radiological, biological } \\
\text { weapons and their abuses } \\
\text { Space encroachment } \\
\text { Weapons of mass destruction and nuclear proliferation }\end{array}$ & $\begin{array}{l}\text { The global political dimensions } \\
\text { Human rights and rule of law; Democracy and autocracy } \\
\text { Emergence of new regional and global powers } \\
\text { Political interferences and interventions } \\
\text { Demographic politics (displacement, refugees, migration) }\end{array}$ \\
\hline
\end{tabular}

Source: Adapted from Upreti, 2012b

Often after large scale political changes (either regime change or system change) security sector falls on contestation or controversy, blamed for wrongdoing and not ineffective and therefore demands for review and reform (Sharma et al 2012; Bhattarai \& Cave, 2009; Sapkota, 2009; Upreti, 2012b). It also demands for developing a comprehensive national policy for security sector to gives broader framework for future decision on security related issues, to make security sector more acceptable, respected and institutionalized. Security sector need to be owned by political parties and citizens irrespective of their political affiliation of orientation towards particular political party/ideology. While developing such policy, three fundamental components: i.e., state security, human security and societal security (See figure 4) are crucially important because they are complementary to each other and conceptually coherent and make a holistic framework.

\section{Figure 4: Basic Components of New National Security}

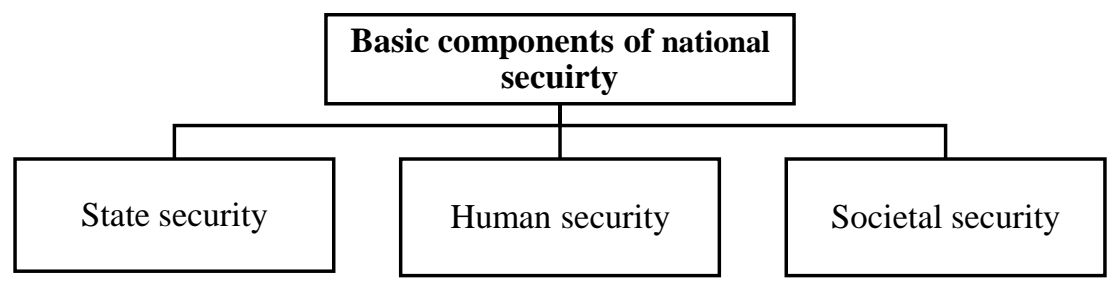

Source: Upreti (2012b)

State security often focuses on the state sovereignty and territorial integrity, and the military is assigned to maintain the sovereignty and territorial integrity. Human security focuses on the human dimension such as ensuring basic human rights, food and water, right to health and so on. Societal security refers to the broader security concerns of society as a whole such as securing the public from natural calamities, disasters and disease pandemics, protecting public property and public places (Lulian et. al., 2008). Romania, Moldova, Ukraine, Australia, USA, Canada, Finland, Germany, New Zealand, UK and Netherlands have incorporated societal and human security dimensions in addition to state security in their national security policy ${ }^{2}$. In the new and changing global, regional and national political context societal security is fundamentally important (Government of Australia, 2009; Government of Canada, 2004). However, it is not getting right priority in the policy making and political decision making levels.

\footnotetext{
2 See a) Finish Security and Defense Policy 2009 (Prime Minister's Office Publication 13/2009, b)Securing a Open Society: Canada's National Security Policy April 2004; Canada Privy Council Office' c) Defense Policy Guidelines for the area of responsibility of the Federal Minister of Defense, Germany, 21 May 2003, d) National Security Strategy of the Netherlands, Ministry of Interior and Kingdom Relations, May 2007, e) The New Zealand Defense Force Strategic Plan 2007-2011, Ministry of Defense, and f) National Security Strategy of the United Kingdom: Security in the Interdependent World. See the Cabinet Office, March 2008, for details about the inclusion of societal security in their national security policies and strategies.
} 
Figure 5 presents different dimensions of societal security on which Nepal has to give priority in the coming decades.

Figure 5: Different Dimensions of Societal Security

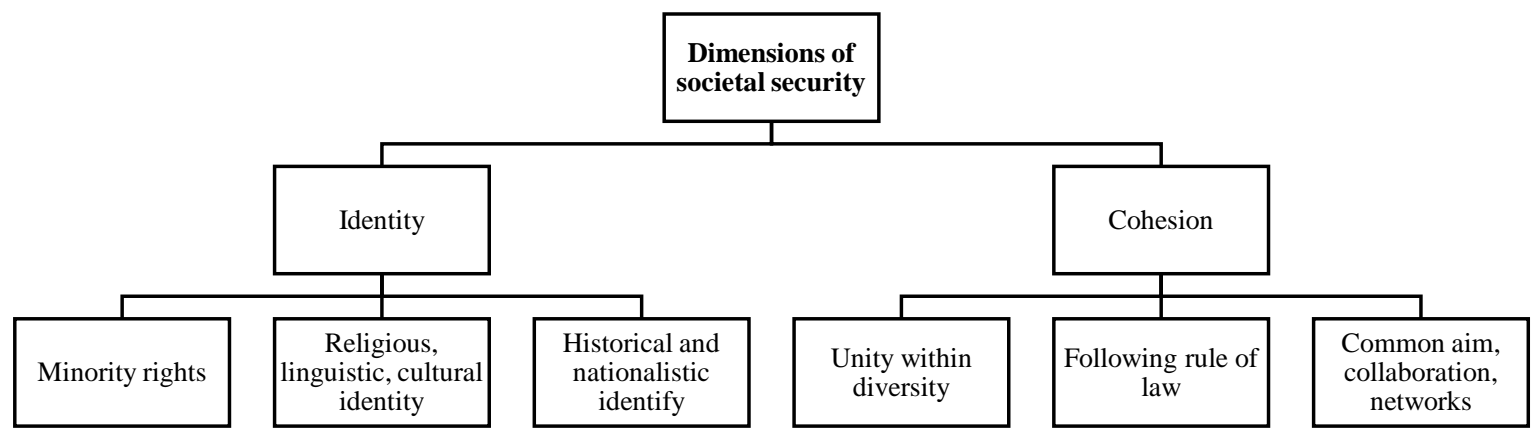

Source: Upreti (2012b)

Societal security is affected by and related to many factors, which can be grouped into two, i.e. identity and cohesion. For identity, it is important to respect minority rights and protecting religious, linguistic and cultural identity without affecting others rights and identity. Further, respecting historic identity of particular groups is crucially important and has to go side by side with acknowledging and enhancing national identity for achieving societal security. Cohesion brings unity within diversity, respecting plurality ad mutual respects. If we fail to balance between identify and cohesion it potentially becomes a perennial source of tension and conflict and poses domestic security challenges and provides space for external force to engage in.

Figure 6: Different Challenges to Security

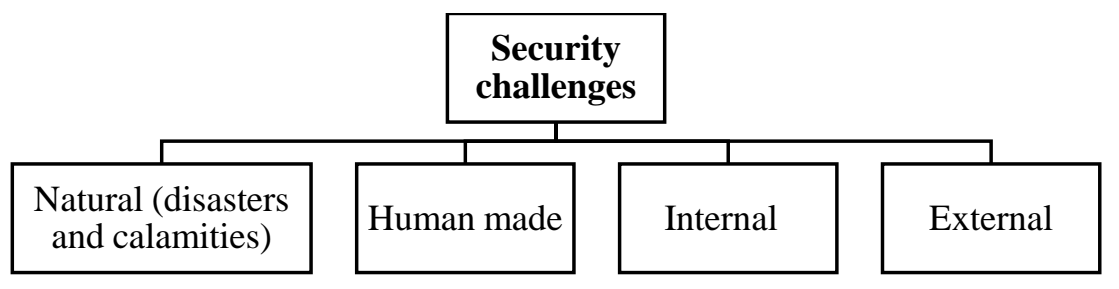

Source: Developed by author

Security is a major challenge anywhere in the world and every country allocates essential resources to tackle insecurity and to provide security to its citizens. Conceptually security challenges can be categorized into two interrelated category:

- Based on externality: external and internal security challenges

- Based on source: natural (disasters such as flood and landslides, earthquake, tsunami, drought, forest fire and so on) made and manmade (blockade, political violence and insurgencies, religious, ethnic or other form of bloody conflict and civil war, nuclear/radioactive, biological and chemical contaminations and attacks, pollutions, breaking of big infrastructures, food shortage etc.)

Figure 7: Fundamental Basis of Societal Security

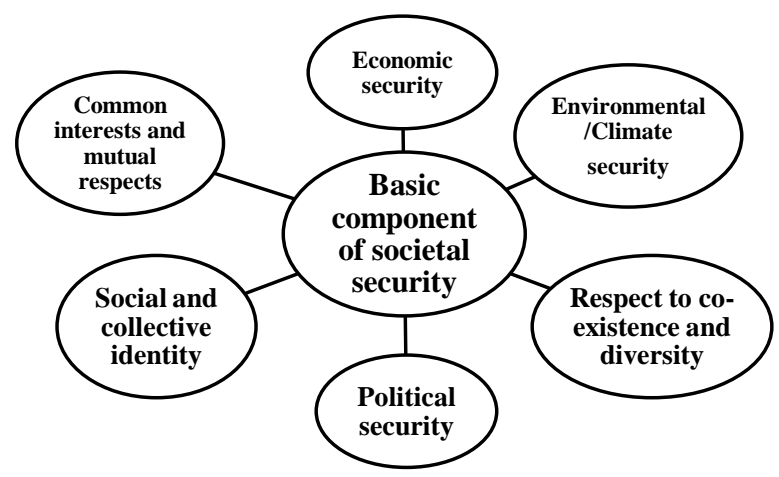

Source: Upreti (2012b) 
In political security, full participation in politics and appropriate representations (proportional representation could be one best option) are some of the important elements. In economic security, livelihood security of individuals and employment opportunities are important. Ensuring opportunities for securing basic livelihoods and health and education are crucial for the economic security. In environmental security, judicial use, balancing the ecological and economic use of environmental and natural resources and protecting and preventing environment from the effects of climate changes are crucial. Further, collective commitment (achieving security is a common concern of all citizen) and society's collective identity (uniting rather than fragmenting into smaller identity) are fundamentally important to achieve security in the coming many years. Hence, preventing radicalization of ethnic religious sensitivity and causing intolerance and ignoring the co-existence requires appropriate handing of these issues.

Societal security has to provide security and protection to population and vital infrastructures (hydropower, telecommunications, roads and suspension bridges, airports, industrial estates, etc.) from human made disasters and natural calamities. Further, provision of fire safety, road safety, defining construction standards to protect from construction hazards, ensuring livelihood (food, drinking water, health) security, environmental security and security from adverse effects of climate change are important components of the societal security, in addition to the conventional areas of state security (state's ability to defend against external threats). Promoting collective efforts for social welfare, mutual respects and co-existence must be priority for the national security for coming three decades.

Any future security framework must be able to tackle conventional and unconventional security challenges. In case of Nepal we need to develop our national security capacity to tackle the problems such as:

- Natural calamities and disasters (earth quakes, landslides, flooding, droughts, forest fire, avalanche, etc.),

- Manmade disasters like nuclear/radioactive, biological and chemical contaminations and attacks, pollutions, breaking of big infrastructures, food shortage, disaster from misuse of science and technology

- Pandemics like bird flu, SARS, HIV Aids, Hepatitis and other outbreaks

- Information (electronic war, cybercrime), space security (mainly missiles, navigation and aeronautics), etc.

- Strategic implications of rise of India and China, two giant neighbours

- Expansion of global terrorism (e.g., Al Quaeda) and its focus in South Asia (India, Pakistan, Afghanistan) (though Nepal is not a primary target country so far but the possibility exists for both soft (big public places such as cinema halls, malls and super markets, airports, bus stations, temples and churches, etc.) and hard targets (security stations and camps, ministries and government building, etc.).

- Organized crimes: narcotises, money laundering, smuggling of small arms, human bodies, abuses of inflammables and explosives

- Energy crisis, resource scarcity

- Demographic change and challenges (migration, displacement, high ration of aging population, etc.)

- International vested interests and pushing Nepal (knowingly or unknowingly) in risky and dangerous controversies (e.g., peace conference of unification church, engaging in and pulling form BIMISTIC related joint military exercise,) or extracting our valuable natural resources, etc.

- Governance challenges (respecting Rule of Law and constitutional provisions, balancing confidentiality and transparency, ensuring accountability, combating corruption, overcoming duality and hypocrisy, etc.)

\section{Human Security and Its Components}

One of the prime concerns in the contemporary security debate is ensuring human security which is more fundamental ad directly related to the life and livelihood of people. The following figure 8 shows the important elements to be considered for ensuring the human security: 
Figure 8: Fundamental Basis of Human Security

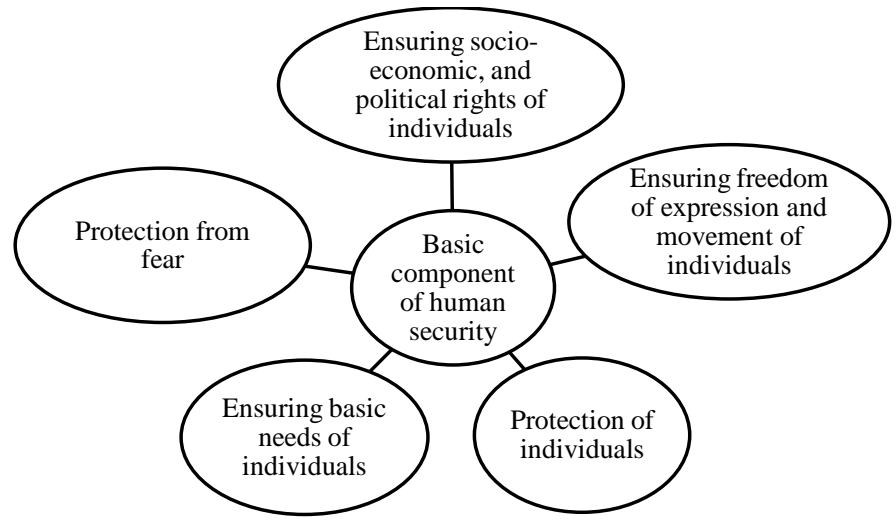

Source: Upreti (2012b)

Human security is one of the major security concerns in the changing context, where state security alone is not enough to protect individual citizens of any country. There are other interrelated components form human security, i.e. a) protection of individual from fear, b) ensuring individuals' basic needs, c) physical protection of human being, ensuring individuals' freedom to express and move, and d) ensuring socioeconomic, political, religious and cultural rights. The human security perspective is therefore driven from the human rights perspective too. It has to be complimented by the state security to make the nation secure.

\section{State Security and Its Components}

The basic components of the state security comprises of protection of strategically important areas, and structures; assurance of national sovereignty and territorial integrity; protection of important dignitaries of the state; protection and control of border areas (particularly security sensitive areas); securing of state and people from external invasion; and help/protection of people from natural calamities and manmade disaster (Upreti et al. 2013, 2015 \& 2016; Upreti 2010; 2012ab). The major components of the state security are presented in Figure 9 below:

\section{Figure 9: Fundamental Basis of State Security}

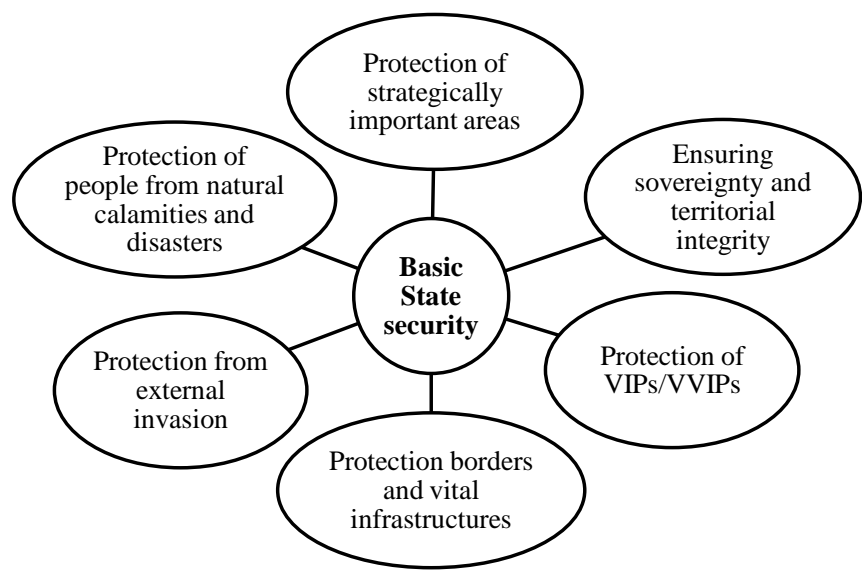

Source: Upreti (2012b)

\section{Security in Federal System}

Managing security in the federal set up is a daunting task and it is even more complicated when federalization is initiated in a unitary country with established security infrastructures. It is mainly because:

- Too difficult in negotiating power and authority between the federal units,

- Lack of experiences in dealing with and managing security in the federal structure (In Nepal federalization was outcome of the frustration and negative perception about unitary system and therefore always focuses on dismantling central power. However, security is a very sensitive issue and a lot of special power need to be vested in the federal level which often the federated units do not like that ultimately invites tussle and tension). 
- Covert interests of external forces also indirectly play with resistance or manipulation.

- Lack of substantial debate on managing security at provincial and local governments especially on structures, size and responsibility of security structures in the changing context. It is crucially important to adapt participatory and inclusive approaches that ensure constructive engagement of public in security debate where they assist the state to achieve security. Engagement of public not only develops ownership but also helps to win the hearts and minds of people to tackle the security concerns and challenges of the country.

- Confusion created by the influence or copying of different practices/arrangement of security management in different federal countries, which are not totally relevant because of our specific context, need and capabilities.

- In many federal countries often military are kept in the central level and paramilitary like Armed Police Force, Nepal are kept in both central and state level but often police are kept at province levels. In case of Nepal, the constructive debate is still lacking on the roles, size and structures of security forces in relation with the current context.

- Developing competent human resource is essential to strengthening Nepal's security. Nepal is situated in geo-politically very strategic place and role of security intelligence is crucial. The rise of China as super power and the economic development of India, growing interests of USA in the region, Indo-Pak tension and nuclear expansion in the region, concentration of millions of poor people, water stress and food insecurity make South Asia strategically important from the security perspective and Nepal is in the centre geo-politically. Therefore, developing competent human resources capable of implementing the long term security vision is crucially needed. Hence, human resource development through academic courses, offering training courses, creating research institute for the security/strategic research and engage in security analysis, early warning, risk assessment and thereat analysis are crucially important for Nepal.

- Nepal has already changed the narrow security vision but needed enabling environment. Tackling potential security challenges for coming decades needs a new approach to make country safe, secure and peaceful for which the government must create enabling environment for tackling these challenges.

- Role of National Security Council need further strengthening. A fully functional, highly competent professional body responsible for advising the government on the security policy, strategy is precondition. It will have to take decision based on strategic analysis, research, and early projections, threat and risks assessment. Also provide suitable environment for army, police and armed police forces to grow in a highly professional, competent, modern security structures.

- The government and the parliament need to ensure that all 3 state security forces operate according to the internal standard practices. Their relation with people is cordial, political parties do not interfere the security structures. They operateunder the full civilian control and parliamentary oversight to enhance credulity of security structures and make them respected at national, regional and international levels.

- Strengthen intelligence: In the changing context (domestically federalization and externally several vested interests and emergence of radical nationalistic behavior of powerful countries ignoring the principle of co-existence) Nepal need a highly professional, extremely intelligent, regionally and internationally recognized organization operates globally to strengthen the national interests, state security, human security and societal security and enhances visibility and recognition of the country in the world.

- Issue of border security is becoming even complicated in the federal set up as role of provinces is crucially important in facilitating border issues. In addition, Nepal's forces have also to deal with the security of tourists, ensuring industrial security forces. Disaster risk reduction, relief and humanitarian assistance are other important areas where security forces of Nepal have gained great experiences from their past engagements. Based on the experiences so far, Nepal needs to establish a very effective and resourceful humanitarian assistance mechanism fully functions to assist the people of the country. As Nepal has gained excellent experiences in disaster management it can provide expert service to disaster related problems across the globe.

- Integrated strategy: It is utmost essential to integrate security policy, foreign policy, development policy and economic policy of the nation. Nepal's international relation policy have to entail security, 


\section{0 | Journal of APF Command and Staff College}

economy, human rights as integral components and Nepal's foreign policy influences economic, security and political decision making at regional level.

- Establishment of, and investment in, specialized research and analysis must be one of the core priority of Nepal to strengthen the security. Nepal needs to develop highly competent, globally renounced research and analysis think tanks and research institutes in the areas of security, international relations, and strategic issues if it wants to be secure. Further, Nepal has to have sophisticated laboratories for biological, chemical, radiological and other security related tests and they will be recognized in the region and beyond. Demands for their professional services will increase globally.

- It is urgent to establishing and strengthening defense science and technology in Nepal. Nepal has to have specialized defense sciences and technology centres to study space security, information security, climate monitoring, to counter bio-terrorism etc.

\section{China-India Factor and Our Security Concerns}

\section{China}

As Nepal is situated in a geo-strategically sensitive place between the competing giants China and India, security sensitivity is one of our prime concern especially when both of them have multifaceted contested issues and with multi-polarization, they are one of the largest geo-political, geo-economic and geostrategic actors in the global distribution of power able to challenge the existing world powers (e.g., USA, Japan, France, UK). In this context once Kevin Rudd (former MP of Australia) in his key note speech at London (16 Dec 2013) said, "I believe the single great challenge of our age is the rise of China and its impact on the current international order", referring to China's economic and political rise. Western strategists often emphasize that in coming decade Chinese will surpass USA in terms of economic and military power parity as economic power and ultimately shapes strategic and political powers. The worry of Western power in relation with the Chinese expansion is reflected that a nonwestern, non-English and non-democratic country to be world's largest power in future and they are concluding that whatever change in the current world order may occur will be due to rise of China (and other southern countries).

Similarly, China and India are competing among themselves in global order: economic, security, global structures (UN-UNSC, IMF, WB) and engaging in maritime security regime, developing space based security technology including cyber security, concerned with non -traditional security concerns (climate and environment, food and water; migration, health and education, energy. They are also competing for regional security (geopolitics of particular geographical areas especially: South Asia, South-East Asia, Asia Pacific, Africa), but want a stable Asia-Pacific to sustain their economic prosperity. However, their alliances are different. India seeks US presence to minimize possible Chinese excesses, where as China views US containment attempts in the region.

The geopolitical revelry is one of the major factors for Sino-Indian relations. The major ones are a) Dalai Lama-India relations and China's concerns, b) Pakistan-China relations and India's concerns, c) expanding influence in South Asia: (India's concern over China's influence in Sri Lanka, Maldives Bangladesh, Nepal and Pakistan through major infrastructure development-belt and road initiative, defense cooperation, trade (for example, China had provided submarines to Bangladesh and now China is largest trading partner of BD, after 28 years Chinese President Xi Jinping visited Bangladesh Oct 2016 and signed 27 agreements. Likewise, in 2015 Indian PM Modi visited Bangladesh and singed 22 agreements. This is a concrete example how these two countries are competing in the region.

China is funding large projects in South Asia, for example China-Pak Economic Corridor, Hambantota port and Norochcholai Thermal Plant in Maldives; which are of concern of India. Further, India and China has some unsettled issues constantly affecting their relations. One example is the historical tension on Arunachal Pradesh (China views that Arunachal Pradesh is in India only because of McMahon Line drawn in 1911 otherwise it should be in South Tibet. China had furious reaction when India allowed Dalai Lama to visit Arunachal Pradesh on 4 April 2017 (and received and accompanied by India's junior home minister Kiren Rijiju) as the Indian ambassador at Beijing was summoned and handed over the formal protest with strong worded statement (harming the bilateral relations and facing the consequences). China had also opposed US supported Indian interest to be member of Nuclear Suppliers Group., China also built China-Pakistan Economic Corridor through disputed Kashmir against Indian 
interests. India was furious on China built ports (e.g., Gwadar of PK, Container terminal at Colombo) and large infrastructure investment in Pakistan, Sri Lanka, Bangladesh; engagement of China in peace talk between Afghan Taliban and the Afghan government. However, despite these rivalries both countries are trying to improve relations: President Xi Jinping was birthday guest of PM Modi in 2014 in his hometown Ahmedabad, Modi lifted restrictions imposed by previous Indian government on Chinese investment on sensitive sectors such as ports and telecoms.

China is massively engaged in oil industries, mines and minerals, dams, trade, private business and development infrastructures around the world that became instrumental to international expansion of China. China aims to turn economic strengths into strategic expansion through new cooperation platforms like Shanghai Cooperation Organization (SCO), BRI, BRICS, and Asian Infrastructure Development Bank to weaken the hegemony of conventional power and strategic means to expand economic influence. Another means of influence is China's Indian Ocean Strategy (which has greater focus on sea and expansion of naval base to be a 'major maritime power') and aim to expand maritime routes (maritime silk road initiative) to Middle East and beyond through Indian Ocean as bridge between Asia and Europe and Africa, its strategy to expand to Indian Ocean Rim (Australia to Middle East and South Africa). Further, it has increased investment in defense (35 billion \$ in 2006 to 141 billion \$ in 2015). In 2021 China is celebrating century of founding of Chinese Communist Party and in 2049 it will mark century of People's China where China is working to materialize "duel Century Goals' for which by 2021 it will 'complete the building of a moderately prosperous society in all respects' and by 2049 it will 'build a modern socialist country that is strong prosperous, democratic, culturally advanced and harmonious', what Xi Jinping says "Dream for China's future". China is also having lead role in UN International Finance Cooperation and becoming influential in issues like climate change and sustainable development.

China sets up the Central National Security Commission (CNSC) to advise the politburo and highest level of leadership responsible for security strategy; to coordinate between different departments of party, government, military and society and assessing external and internal security threats and crisis management. These all Chinese strategies and activities will have covert or overt effects (both positive and negative) for Nepal.

\section{India}

Indian Prime Minister Narendra Damodar Modi adjusted Indian foreign policies and strategies to make more 'progressive', assertive' and 'prominent', and mobilized Indian diaspora. His international relations were focused on economic advancement and he made efforts for global outreach to expand Indian influence. His priority is to also strengthen cooperation, for example, Free Trade Agreement between India and Eurasian Union, North South Transport Corridor (including Russia, India, Iran) to integrate South Asia, Iran, Central Asia and Russia, expansion of Indian defense cooperation with Russia, hard efforts to secure permanent seat at the UNSC, ensuring Russia-India-China (RIC) bilateral agreements and summits in 2014, These all efforts of Indian will have overt of covert effects (both positive and negative) to Nepal and we need to be able to deal with the negative effects of both neighbours.

Similarly, changing global power dynamics, advancement of sciences and technologies (IT, quantum physics, etc.), globalization and market domination (arms trade), emerging global security risks (chemical and biological weapons, space wars, etc.), securitization of movement, effects of terrorism, pandemics, international migration multiplied by the globalization and environmental insecurity, scarcity of energy resources (it is at the heart of future inter-state conflicts) and increasing military spending in all BRICS countries (they were among the top ten military spenders in 2011 with China occupying second place (after the US), Russia third, India eighth, and Brazil tenth), increasing world's population (1.6 billion at the beginning of the 20th century that will reach 8 billion by 2030, and more than 9 billion in 2050); dramatic increase in population growth in Muslim countries (Bangladesh, Egypt, Indonesia, Nigeria, Pakistan, and Turkey) and negative population growth rate in developed countries, growing marginalized population (one billion people, 1/6th of the world's population live in slum with very lowpaid jobs, unemployment: begging, drugs, prostitution, and crime \& urban violence); emergence and expansion of radicals, extremists and terrorists (e.g., al-Qaida, Islamic State in Iraq and the Levant, Boko Haram, etc.), possible manipulation against one China policy (Tibet + Taiwan), South China Sea dispute (border to determine according to the 'nine-dash line'), disputed borders/territories in Senkaku (Diaoyu) 


\section{2 | Journal of APF Command and Staff College}

islands, East China Sea, Kuril Islands, The Korean peninsula, Western Sahara, Antarctica, Israel/Palestine, Somaliland, Taiwan, Jammu \& Kashmir etc.), expanding terrorist networks and counter terrorism responses (investment in military capabilities, human rights abuses, etc.) potential dispute on capturing global commons, secessionist tendencies in Tibet; terrorist and secessionist activities in different parts of world (e.g., in Xinjiang of China, North East Indian states); territorial disputes in South China sea with Japan and South Korea Vietnam; extraction of resources from poor countries (investment in infrastructure and other lucrative areas) are some of the factors directly and indirectly shaping global, regional and national security concerns in future and we have to prepare to deal with the effects. Nepal to work for balancing relations (neutrality, equi-distance, non-alignment etc.), develop negotiation capacity and ability to deal with contested issues (infiltration of separatists and terrorists and other forces interested to destabilize China and India), handling regional water scarcity and tension, effects of volatile population of South Asia affected from poverty, inequality, discrimination, ethnic and religious tensions, balancing the interests of India, United States, China, EU countries for strategic, economic, political concerns, and ensuring the Nepal's national interests while dealing with external interests.

\section{Conclusions}

So far, direction taken by Nepal in dealing with new security challenges is right but need more efforts at the national, provincial, and local levels to create enabling environment. Enabling environment includes favourable legal-regulatory provisions, supportive institutional arrangement, required resources, investing in capacity development especially in education and research, developing sound intelligence and integrating security policy with international relations, economic development and social services. Further, expanding the security discourse and engaging citizen of the country to develop ownership is essential for which the government need a dedicate programme on strengthening relationship between citizen and security actors of the country. Moving from narrow, militaristic, centralised security arrangement to a holistic security arrangements discussed in the preceding section require time, commitment, resources and therefore it has to be national priority going beyond certain ministries or security agencies.

Security concerns are not limited to military and state security forces and therefore it has to integrate, economic, foreign, development policies into national security policies. The going to be soon revised National Security has to ensure this arrangement. The National Security Council has to ensure strong coordination mechanism among the concerned ministries (Defence, Home, Foreign Affairs, Federal Affairs and General Administration, Communication and Information, Ministry of Education, Science and Technology) and collaboration with key stakeholders (central, provincial and local governments, experts and academics and civil society).

Creating enabling environment (developing relevant policy and strategies, promulgation of laws and development of rules and procedures, creating responsive institutional mechanisms, developing capabilities, making required resources available, parliamentary oversight and monitoring provisions, invest in security research and education) is a pre-condition for addressing the security challenges of $21 \mathrm{st}$ centuries (unconventional security challenges such as resource scarcity, climate change effects, livelihood insecurity, environmental insecurity, food and water insecurity, health insecurity, natural calamities and disasters, pandemic diseases, etc.) as well as conventional security issues such as protecting sovereignty and territory of the state.

Global economic and strategic power is shifting from US to China and therefore China will be most influential in the world order in coming few decades which will have direct effects to Nepal. Economic and geo-political interests will be the determinants of the engagement of China and India in future with any countries including Nepal. Small countries like Nepal will have hard time (economically, politically, strategically) to deal in the changing global order (protecting national interests in a situation of aggressive approaches of old and emerging powers). China and India are surely going to change geopolitics and it will have great effects (both positive and negative) to Nepal. Nepal has both opportunities and challenges for its geo-strategic location but risks are high (use for vested interested by the powerful countries as Nepal is still weak in negotiation. Most difficult aspect for Nepal will be the rivalry and competing priorities of India and China on major global issues (e.g., Asian security, regional stability in S/E Asia) and their attempts to get support of Nepal. 


\section{References}

Australian Government. (2009). Defending Australia in the Asia-Pacific century force 2030 (Defense White Paper 2009). Sydney: Department of Defence, Australian Government.

Bhattarai, R. \& Cave, R. (2009). Changing security dynamics in Nepal. Kathmandu: NIPS and Safer World.

Government of Canada. (2004). Security on open society: Canada's national security policy. Toronto: Canada Privy Council Office.

Hough, P. (2004). Understanding global security. Rutledge: London and New York.

Huntington, S. (1985). The Solider and the state: The theory and politics of civil-military relations. New Delhi: Natraj Publications.

Iulian, C., Oazu N., \& Oleksander, S. (2008). Societal security in the trilateral region of Romania-UkraineRepublic of Moldova. (Place and publisher not mentioned).

Phuyal, H., \& Urscheler, M. (2010). The security sector legislation of the Federal Democratic Republic of Nepal: Commentaries. Geneva: Democratic Control of Armed Forces (DCAF).

Sapkota, B. (2009). A compendium of security sector of Nepal. Kathmandu: National Peace Campaign and Centre for Democratic Control of Armed Force.

Sharma, S. R., Upreti, B. R., \& Pyakuryal K. (2012). (Eds.). Nepal 2030: A vision for peaceful and prosperous nation. Kathmandu: NCCR North-South.

Upreti, B. R., Sharma, S.R., \& Paudel, S. B. (2016), Food security in post conflict Nepal: Challenges and opportunities. New Delhi: Adroit Publishers.

Upreti, B. R. (2015). Armed conflict and its impacts in Nepal (in Nepali language). Kathmandu: NCCR.

Upreti, B. R. (2015). Peace process and challenges of state building in Nepal (in Nepali language). Kathmandu: NCCR.

Upreti, B. R., Butler, C., \& Maharjan, K. (2015). Climate insecurity and conflict in South Asia: Climate variability as a catalyst for social tension and insecurity. New Delhi: Adroit Publishers.

Upreti, B. R. (2014), Nationalism and militarization in Nepal: Reactive response or long-term phenomenon?. Asian Journal of Peace buildingVol. 2 No. 2 (2014): 217-239.

Upreti, B. R., Bhattarai R., Wagle, G.S. (2013). (eds.). Human security in Nepal: Concepts, issues and challenges. Kathmandu: Nepal Institute for Policy Studies (NIPS) and South Asia Regional Coordination Office of NCCR North-South.

Upreti, B. R. (2012a), Nepal from war to peace. Peace Review: A Journal of Social Justice, 24:1, 102-107.

Upreti, B. R. (2012b). Security for peace and stability. In Sharma SR, Upreti BR, and Pyakuryal K. (2012). (Eds.), Nepal 2030: A Vision for Peaceful and Prosperous Nation. Kathmandu: NCCR North-South. Pp. 93-110.

Upreti, B. R. (2010). Political change and challenges of Nepal: Reflection on armed conflict, peace process and state building. Volume I and II. Saarbrucken: Lambert Academic Publishing.

Upreti, B. R. \& Vanhoutte, P. (2009). Security sector reform in Nepal: Challenges and opportunities. In Born H, Schnabel A, (eds). Security Sector Reform in Challenging Environments. Geneva: LIT Verlag, pp. 165-187.

Upreti, B. R. (2009a). Nepal - From war to peace: Legacies of the past and hopes for the future. New Delhi: Adroit Publishers.

Upreti, B. R. (2009b). Civil society engagement in security sector transformation in Nepal. In Sapkota, B. (ed.) A Compendium of Security Sector of Nepal [in Nepali]. Kathmandu: National Peace Campaign and Centre for Democratic Control of Armed Force, pp 353-370. 